quả điều trị tương đương TDF về tỉ lệ tải lượng HBV DNA âm tính (< 29 UI/L); tỉ lệ mất HBeAg, và chuyển đổi huyết thanh anti-HBe có sự khác biệt không có ý nghĩa thống kê giữa 2 nhóm. Tuy nhiên, trên nhóm BN điều trị TAF có tỉ lệ đạt ALT bình thường ở những bệnh nhân có mức ALT ban đầu cao sau 96 tuần điều trị là $75 \%$ so với nhóm điều trị TDF là $68 \%$, và sự khác biệt này có ý nghĩa thống kê, $p=0,017$.

Nghiên cứu của chúng tôi khảo sát trên 111 $B N$ với nhóm điều trị TAF $37 \mathrm{BN}$ và TDF là 74 BN. Nhóm BN điều trị TAF có độ tuổi trung bình là 41 , tỉ lệ nam giới $72 \%$, ALT trung bình $27 \mathrm{UI} / \mathrm{L}$ so với nhóm BN điều trị TDF lần lượt là 37; $66 \%$ và 48 UI/L. So với nghiên cứu của Kosh Agarwal thì nhóm BN điều trị TDF của chúng tôi có độ tuổi trung bình trẻ hơn. Trong cả 2 nhóm BN điều trị TAF hoặc TDF đều có sự tương đồng với nghiên cứu của Kosh Agarwal về tỉ lệ nam giới chiếm ưu thế hơn so với nữ giới; về mức ALT trung bình trong nghiên cứu của chúng tôi đều thấp hơn. Sau 48 tuần điêu trị, chúng tôi cũng khảo sát thấy hiệu quả điều trị tương đương nhau giữa 2 nhóm BN điều trị TAF hoặc TDF về tỉ lệ tải lượng HBV DNA âm tính. Có sự khác biệt khồng có ý nghĩa thống kê về tỉ lệ mất $\mathrm{HBeAg}$, tỉ lệ đạt ALT bình thường giữa 2 nhóm điều trị. Tuy nhiên nghiên cứu của chúng tôi có hạn chế do là nghiên cứu hồi cứu, cõ mẩu nhỏ, thời gian theo dõi mẫu ngắn.

\section{KẾT LUẬN}

Kết quả nghiên cứu cho thấy sau 48 tuần, hiệu quả điều trị tương đương nhau giữa 2 nhóm BN điêu trị TAF hoặc TDF về tỉ lệ tải lượng HBV DNA âm tính. Có sự khác biệt không có ý nghĩa thống kê về tỉ lệ mất $\mathrm{HBeAg}$, tỉ lệ đạt $A L T$ bình thường giữa 2 nhóm điêu trị TAF hoặc TDF.

\section{TÀl LIÊU THAM KHẢO}

1. Fattovich G, Bortolotti F, Donato F. Natural history of chronic hepatitis B: special emphasis on disease progression and prognostic factors. ] Hepatol. 2008; 48 (2): 335-352.

2. Agarwal $K$, Fung $S K$, Nguyen $T T$, Cheng $W_{\text {, }}$ et al. Twenty-eight day safety, antiviral activity, and pharmacokinetics of tenofovir alafenamide for treatment of chronic hepatitis B infection. J Hepatol.2015; 62(3):533-540.

3. Chan $H L_{\text {, Fung }} S$, Seto $\mathbf{W} K$, Chuang $\mathbf{W} L$, et al. Tenofovir alafenamide versus tenofovir disoproxil fumarate for the treatment of $\mathrm{HBeAg}$ positive chronic hepatitis $B$ virus infection: a randomised, double-blind, phase 3, non-inferiority trial. Lancet Gastroenterol Hepatol. 2016; 1(3):185-195.

4. EASL clinical practice guidelines. EASL 2017 Clinical Practice Guidelines on the management of hepatitis B virus infection. J Hepatol. 2017; 67(2):370-398.

5. Agarwal K, Brunetto $M$, Seto $W K$, Lim $Y S$, et al, (2018), "96 weeks treatment of tenofovir alafenamide vs. tenofovir disoproxil fumarate for hepatitis B virus infection", J Hepatol. 2018; 68(4):672-681.

6. Vittal A, Ghany MG. WHO Guidelines for Prevention, Care and Treatment of Individuals Infected with HBV: A US Perspective. Clin Liver Dis. 2019; 23(3):417-432.

\title{
ĐÁNH GIÁ HIỆU QUẢ LASER TẠO HÌNH VÙNG BÈ CHỌN LỌC TRÊN BỆNH NHÂN GLÔCÔM GÓC MỞ ĐÃ ĐƯợC ĐIỀU TRI BẰNG THUỐC HẠ NHÃN ÁP
}

\author{
Đỗ Tấn1, Phạm Thị Thu Thủy², Nguyễn Đức Thịnh² \\ TÓM TẮT \\ Mục tiêu: Đánh giá hiệu quả tạo hình vùng bè \\ chọn lọc bằng laser trên bệnh nhân glôcôm góc mở đã \\ được điều trị bằng thuốc tra hạ nhãn áp. Đối tượng \\ phương pháp nghiên cứu: Nghiên cứu mô tả đã \\ thu nhận 40 mắt trên 28 bệnh nhân glôcôm góc mở

\footnotetext{
${ }^{1}$ Bệnh Viện Mắt Trung Ương

Đại Học Y Hà Nội

Chịu trách nhiệm chính: Đỗ Tấn

Email: dotan20042005@yahoo.com

Ngày nhận bài: 2.2.2021

Ngày duyệt bài: 29.3.2021
} \\ Ngày phản biện khoa học: 18.3.2021 \\ nguyên phát và glôcôm thứ phát do thuốc đã tra \\ thuốc ha nhãn áp, được tạo hình vùng bè chọ loc \\ bằng laser $360^{\circ}$. Tình trạng thị lực, thị trường, nhã̉n \\ áp, góc tiền phòng, đáy mắt, thông số laser, số thuốc \\ tra được đánh giá tại các thời điểm trước và sau điều \\ tri 2 tuần, 1 tháng, 3 tháng. Kết quả: đô tuổi trung \\ bình là 48,95 $\pm 15,76$, tỷ lệ nam/ nữ tương đối đồng \\ đều $(55 \%$ và $45 \%)$; thời gian mắc bênh trung bình \\ 21,33 \pm 31,2 tháng; đa số bệnh nhẩn ở giai đoạn \\ bênh trung bình và nặng. Nhãn áp trung bình trước \\ điều trị là $27,48 \pm 5,92 \mathrm{mmHg}$, giảm xuống $20,05 \pm$ \\ $4,36 \mathrm{mmHg}$ ở thời điểm 2 tuân; $17,98 \pm 5,73 \mathrm{mmHg}$ ở \\ thời điểm 1 tháng; $16,36 \pm 3,58 \mathrm{mmHg}$ ở thời điểm 3 \\ tháng với tỷ lệ ha \% nhãn áp tương ứng là $26 \% ; 31 \%$ \\ và $39 \%$. Số thuốc tra trung bình trước điều trị là 3,05 \\ \pm 0.75 , giảm xuống $2,15 \pm 1,1$ thuốc tại thời điểm 1
}


tháng và 1,76 $\pm 0,97$ thuốc tại thời điểm 3 tháng. Các trường hợp ở giai đoạn bênh sớm và năng có tỷ lệ ha nhãn áp cao nhất ở thời điểm 3 tháng (37-42\%), với những trường hơp ở giai đoan trung bình tỷ lể ha nhãn áp cao nhất ở thời điểm 1 tháng sau điều trị $(38 \%)$. Thị lực, thị trường và tình trạng góc tiền phòng không thay đổi đáng kể sau điều trị. Biến chứng sau điêu trị gồm cảm giác cộm vướng nhức mắt $(7,5 \%)$, cương tụ kết mạc nhe $(10 \%)$ xuất hiện với tần suất thấp, thoáng qua. Kểt luận: Laser tạo hình vùng bè chọn lọc là phương pháp điêu trị an toàn, hiệu quả trong điều trị bệnh nhân glôcôm góc mở đã được điều trị bằng thuốc tra hạ nhãn áp.

Tư khóa: Glôcồm góc mở, laser tạo hình vùng bè chọn lọc (SLT), thuốc hạ nhãn áp

\section{SUMMARY \\ EVALUATING THE EFFICACY OF SLT ON \\ OAG PATIENTS TREATED WITH IOP LOWERING MEDICATIONS}

Objectives: to evaluate the efficacy of SLT on OAG patients who has been treated medically. Patients and methods: Descriptive study on 40 eyes of 28 POAG and steroid-induced patients on IOP lowering medications who have been treated with $360^{\circ} \mathrm{SLT}$. VA, VF, IOP, gonioscopy, optic disc, Laser settings, number of IOP lowering medications were evaluated before treatment and after treatment at 2 weeks, 1 month, 3 months. Results: mean age was $48,95 \pm 15,76$ year old, male/female ratio was comparable (55\% và $45 \%)$; mean duration of disease was 21,33 $\pm 31,2$ months; majority of patients were at advanced or severe stages. Mean IOP before laser was $27,48 \pm 5,92 \mathrm{mmHg}$, which was lowered to 20,05 $\pm 4,36 \mathrm{mmHg}$ at 2 weeks; $17,98 \pm 5,73 \mathrm{mmHg}$ at 1 month; $16,36 \pm 3,58 \mathrm{mmHg}$ at 3 months with equivalent percentage of $26 \%$; 31\%, 39\% respectively. Number of IOP lowering agents before treatment were $3,05 \pm 0.75$, reduced to $2,15 \pm 1,1$ medications at 1 month and 1,76 $\pm 0,97$ medications at 3 months. Eyes at early and severe stage had highest IOP lowering percentage at 3 months (37 $42 \%)$, while eyes at advanced stage had highest IOP lowering at 1 month (38\%). VA, VF and angle remained unchanged after laser. Complications of laser including eye irritation $(7.5 \%)$, mild conjunctival hyperemia $(10 \%)$ were usually transient. Conclusion: SLT was safe and effective in treating OAG patients already on IOP lowering medications.

Key words. SLT, OAG, IOP lowering medications.

\section{I. ĐẶT VẤN ĐỀ}

Glôcôm góc mở nguyên phát là một tình trạng bệnh lý của thị thần kinh, tiến triển mạn tính, có sự kết hợp của nhiều yếu tố, đặc trưng bởi sự chết của các tế bào hạch võng mạc, biểu hiện bằng tổn hại thị trường, lớp sợi thần kinh võng mạc và lõm teo đĩa thị giác. Nguyên nhân thường gặp nhất của những tổn thương này là do nhãn áp cao. Bên cạnh đó rối loạn vận mạch cũng là một yếu tố quan trọng tham gia vào cơ chế bệnh sinh của glôcôm góc mở. Lựa chọn hàng đầu trong điều trị glôcôm góc mở hiện nay vẫn là sử dụng thuốc tra hạ nhãn áp. Tuy nhiên, việc điều trị bằng thuốc có nhiều nhược điểm là giá thành cao, có thể gặp những tác dụng phụ của thuốc, đồng thời đòi hỏi người bệnh phải tuân thủ điều trị thuốc mới đạt hiệu quả duy trì nhãn áp ổn định. Điều trị bằng laser tạo hình vùng bè được ứng dụng từ những năm 1980 cũng cho hiệu quả thành công khá cao: $77 \%$ trong năm đầu tiên, $49 \%$ sau 5 năm ${ }^{1}$. Tuy vậy, laser tạo hình vùng bè tác động trực tiếp lên cấu trúc bè nên có thể gây ra những biến chứng nếu sử dụng năng lượng cao. Phương pháp tạo hình vùng bè chọn lọc bằng laser được Latina và Park thực hiện lần đầu vào năm 1995 đã cho thây những ưu điểm nổi trôi. Nhờ chỉ tác động chon loc lên các tế bào sắc tố mà không làm tổn thương các cấu trúc khác nên hạn chế tối đa các biến chứng của laser tạo hình vùng bè2. Sau đó phương pháp này được chấp thuận bởi FDA vào năm 2002, được nhiều các tác giả trên thế giới áp dụng, thu được kết quả tốt. Với những bệnh nhân đã dùng thuốc tra hạ nhãn áp, một số tác giả cũng áp dụng điều trị cho kết quả thành công khá cao, giúp giảm chi phí do thuốc và thuận tiện cho bệnh nhân.

Ở Việt Nam, cho đến nay kỹ thuật này mới chỉ áp dụng đơn lẻ và có một vài báo cáo sơ bộ về kết quả bước đầu của phương pháp taoo hình vùng bè chọn lọc bằng laser trên bệnh nhân glôcôm góc mở. Vì vậy, chúng tôi thực hiện đề tài này với mục tiêu đánh giá kết quả tạo hình vùng bè chọn loc bằng laser trên bệnh nhân glôcôm góc mở đã được điều trị bằng thuốc tra hạ nhãn áp.

\section{II. ĐỐI TƯƠ'NG VÀ PHƯƠNG PHÁP NGHIÊN CỨU \\ Đối tượng nghiên cứu. Những bệnh nhân} được chẩn đoán là glôcôm góc mở nguyên phát, glôcôm thứ phát do thuốc $\geq 18$ tuổi; đã được điêu trị bằng $\geq 02$ loại thuốc tra hạ nhãn áp; các môi trường trong suốt đủ để đánh giá tình trạng võng mạc; độ mở góc tiền phòng trung bình $\geq$ 3; đủ sức khỏe để cộng tác và đồng ý tham gia nghiên cứu; điều trị tại khoa Glôcôm Bệnh viện Mắt Trung Ương từ tháng 7/2019 đển tháng 7/2020. Các đối tượng loại trừ khỏi nghiên cứu: bệnh nhân có tiền sử chấn thương mắt; mắc các bệnh lý khác tại mắt như: bệnh giác mạc, đục thể thủy tinh, màng bồ đào, bệnh lý dịch kính võng mạc không cho phép đánh giá tình trạng võng mạc; các trường hợp đã được phẫu thuật nội nhãn và các bệnh nhân mắc hình thái glôcôm khác.

\section{Phương pháp nghiên cứu}


Thiết kế nghiên cứu: Nghiên cứu mô tả.

Phương tiện nghiên cứu: Laser SLT được thực hiện trên: máy Ellex Tango - SLT/ YAG laser.

\section{Cách thức nghiên cứu}

*Khám đánh giá trước điều trị: Bênh nhân được khám về chức năng, thực thể cũng như tình trạng toàn thân; khai thác tiền sử, bệnh sử.

*Kì thuât laser:

- Tra thuốc co đồng tử Pilocarpin 1\% x 2 lần cách nhau 15 phút.

- Gây tê bề mặt bằng tra Dicain $1 \% \times 2$ lần cách nhau 5 phút.

- Đăt kính laser.

- Cài đă̆t thông số laser: kích thước vết đốt: 400um; thời gian: 3nano giây; năng lượng: 0,4-1,4 mJ.

Điều chỉnh hướng ánh sáng chùm tia laser vào vị trí giữa vùng bè sắc tố và vùng bè không sắc tố. Thường bắt đầu bằng năng lượng $0,8 \mathrm{~mJ}$ ở vùng bè có mức độ sắc tố bình thường (độ I và II theo Scheie), $0,6 \mathrm{~mJ}$ ở vùng bè có nhiêu sắc tố (độ III và IV theo Scheie) và $1,0 \mathrm{~mJ}$ ở vùng vè không có sắc tố (độ 0 ). Tăng dần năng lượng cho đến khi thấy có các bọt khí (nhỏ như bọt rượu sâm panh) thì giảm đi $0,1 \mathrm{~mJ}$ và tiếp tục laser ở mức năng lượng đó. Mỗi một phần tư chu vi vùng bè có thể cần điều chỉnh lại năng lượng phù hợp cho phù hợp với mức độ sắc tố của vùng bè. Các nốt laser được thực hiện liên tiếp, cạnh nhau đến khi bao phủ toàn bộ $180^{\circ}$ chu vi vùng bè. Thường là 50 nốt.

- Tháo kính laser và rửa mắt bằng dung dịch sát khuẩn hoă̆c kháng sinh.

- Sau 2 tuần bệnh nhân được chỉ định laser $180^{\circ}$ còn lại của chu vi vùng bè.

*Theo dõi - chăm sóc sau điều trị

- Dùng thuốc ha nhãn áp Acetazolamid $0,25 \mathrm{~g}$ $x 2$ viên/ ngày $x 2$ ngày sau khi laser.

- Thuốc chống viêm non-steroid tra mắt 4 lần/ngày $x 5$ ngày

- Khám định kỳ tai các thời điểm sau điều trị 2 tuần, 1 tháng, 3 tháng, đánh giá tình trạng chức năng, thực thể; thị trường, OCT đánh giá tại thời điểm 3 tháng.

- Nếu bệnh tiến triển thể hiên bằng nhãn áp không đạt nhãn áp đích hoặc thị trường, đĩa thị tổn thương thêm thì bổ sung thêm thuốc tra hạ nhãn áp cho đến khi đạt được nhãn áp đích, nếu vẫn không đạt được thì chuyển phẫu thuật.

*Đánh giá kết quá:

- Kết quả chức năng: thị lực (theo bảng phân loại của WHO 1999); thị trường theo Hướng dẫn điều trị Glôcôm của Hội Glôcôm châu Âu (2014).

- Kết quả thực thể: nhãn áp (Goldmann); độ mở góc tiên phòng (phân loại của Shaffer); sắc tố góc tiền phòng (phân loại của Scheie).

- Đánh giá các biến chứng: cảm giác khó chịu, cộm vướng, tăng nhãn áp thoáng qua, viểm màng bồ đào...

- Đánh giá kết quả chung:

- Thành công: nhãn áp sau điều trị giảm $\geq$ $20 \%$ so với nhãn áp ban đâu hoặc giảm $\geq 1$ thuốc tra hạ nhãn áp so với số thuốc tra ban đầu; chức năng thị giác (thị lực, thị trường) ổn định hoặc tăng; tình trạng lõm teo đĩa thị giác ổn định.

- Không thành công: nhãn áp sau điều tri giảm < $20 \%$ so với nhã̃n áp ban đầu hoặc phải dùng thêm thuốc, laser hoặc phẫu thuật; chức năng thị giác giảm (thị trường thu hẹp, thị lực giảm nhiều còn dưới 20/200); Iõm đĩa tiến triển rộng thêm; có biến chứng nặng gây ảnh hưởng nhiều đến chức năng thị giác và sinh hoạt của bệnh nhân.

\section{KẾT QUẢ NGHIÊN CỨU}

Đặc điểm chung của nhóm nghiên cứu. Nghiển cứu được tiến hành trên 22 mắt của 16 bệnh nhân nam (chiếm 55\%) và 18 mắt của 12 bểnh nhân nữ, tương ứng với $45 \%$ nhóm nghiên cứu. Tuổi trung bình của bệnh nhân tham gia nghiên cứu là 48,95 $\pm 15,76$ trong đó tuổi thấp nhất được điều trị SLT là 19 tuổi và cao nhất là 76 tuổi. Trong 40 mắt của nhóm nghiên cứu, có 28 mắt ở giai đoạn bệnh nặng chiếm $70 \%$, một số ít mắt ở giai đoạn bệnh sớm (12,5\%). Phần lớn bệnh nhân đã sử dụng 3 thuốc tra hạ nhãn áp trước đó với tỷ lệ $45 \%$, chỉ có $25 \%$ bệnh nhân dùng 2 thuốc tra hạ nhãn áp.

Nhìn chung thị lực bệnh nhân ổn định và một số trường hợp tăng tại các thời điểm theo dõi sau điều trị với tỷ lệ thị lực không thay đổi ở các thời điểm 2 tuần là $80 \%, 1$ tháng: $87,5 \%$ và 3 tháng: $84,8 \%$.

Kết quả Nhãn áp

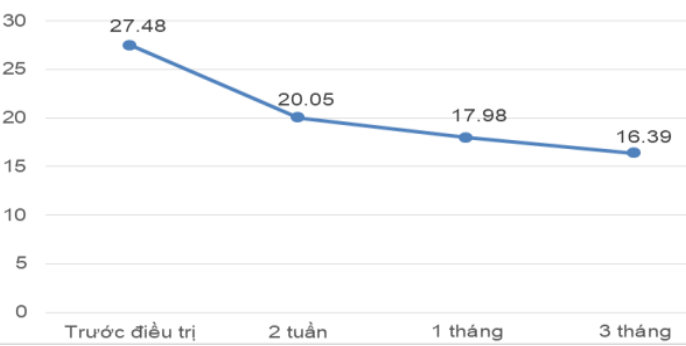

\section{Biêuu đồ 1. Mức ha nhãn áp sau điều tri}

Sau điều trị, mức hạ nhãn áp trung bình so với thời điểm trước điều trị từ 7,43 đến 11,7 mmHg tương ứng với 26 đến $39 \%$. Mức hạ nhãn 
áp và tỷ lê ha nhãn áp tăng dần từ thời điểm 2 tuần đến 3 tháng và đạt mức cao nhất tại thời điểm 3 tháng sau điều trị. Tại thời điểm 1 tháng sau điều trị có 3 mắt và thời điểm 3 tháng có 1 mắt nhãn áp không điều chỉnh phải chuyển điều trị phẫu thuật; có 3 mắt không đến khám lại tại thời điểm 3 tháng sau điều trị.

Bảng 1. Mức hạ nhãn áp theo giai đoạn bệnh

\begin{tabular}{|c|c|c|c|c|c|}
\hline $\begin{array}{l}\text { Giai đoạn } \\
\text { bệnh }\end{array}$ & Thờ & ểm & $\begin{array}{c}\text { Nhã̃n áp TB } \\
(\mathrm{mmHg})\end{array}$ & $\begin{array}{c}\text { Mức hạ NA } \\
(\mathrm{mmHg})\end{array}$ & Tỷ lệ \% NA hạ \\
\hline \multirow{4}{*}{ Nhẹ } & \multicolumn{2}{|c|}{ Trước điêu trị } & $25 \pm 5$ & & \\
\hline & \multirow{3}{*}{ Sau điều trị } & 2 tuần & $19 \pm 3$ & 5,8 & $22 \pm 9$ \\
\hline & & 1 tháng & $17 \pm 2$ & 8,6 & $32 \pm 14$ \\
\hline & & 3 tháng & $17 \pm 1$ & 10,3 & $37 \pm 12$ \\
\hline \multirow{4}{*}{ Trung bình } & \multicolumn{2}{|c|}{ Trước điều trị } & $24 \pm 2$ & & \\
\hline & \multirow{3}{*}{ Sau điều trị } & 2 tuần & $19 \pm 2$ & 5,3 & $22 \pm 7$ \\
\hline & & 1 tháng & $17 \pm 2$ & 6,7 & $38 \pm 7$ \\
\hline & & 3 tháng & $20 \pm 5$ & 4,1 & $18 \pm 19$ \\
\hline \multirow{4}{*}{ Nặng } & \multicolumn{2}{|c|}{ Trước điều trị } & $29 \pm 6$ & & \\
\hline & \multirow{3}{*}{ Sau điều trị } & 2 tuần & $21 \pm 5$ & 8,3 & $27 \pm 16$ \\
\hline & & 1 tháng & $19 \pm 7$ & 9,8 & $31 \pm 29$ \\
\hline & & 3 tháng & $16 \pm 4$ & 13,4 & $42 \pm 21$ \\
\hline
\end{tabular}

Các trường hợp ở giai đoạn bệnh sớm và nặng có tỷ lệ hạ nhãn áp cao nhất ở thời điếm 3 tháng (37 - 42\%), với những trường hợp ở giai đoạn trung bình tỷ lệ hạ nhãn áp cao nhất ở thời điểm 1 tháng sau điêu trị ( $38 \%)$.

Bảng 2. Số thuốc tra sử dụng sau điều trị

\begin{tabular}{|c|c|c|c|c|c|c|}
\hline Shời điếm thuốc & $\mathbf{0}$ & $\mathbf{1}$ & $\mathbf{2}$ & $\mathbf{3}$ & $\mathbf{4}$ & Tổng \\
\hline 2 tuần & $0(0 \%)$ & $3(7,5 \%)$ & $18(45 \%)$ & $8(20 \%)$ & $11(27,5 \%)$ & $40(100 \%)$ \\
\hline 1 tháng & $2(5 \%)$ & $11(27,5 \%)$ & $10(25 \%)$ & $13(32,5 \%)$ & $4(10 \%)$ & $40(100 \%)$ \\
\hline 3 tháng & $2(6,1 \%)$ & $13(39,4 \%)$ & $10(30,3 \%)$ & $7(21,2 \%)$ & $1(3 \%)$ & $33(100 \%)$ \\
\hline
\end{tabular}

Tỷ lệ bệnh nhân không dùng thuốc tăng từ thời điểm 2 tuần sau điều trị (0\%) lên $5 \%$ ở thời điểm 1 tháng và $6,1 \%$ ở thời điểm 3 tháng sau điều trị. Tỷ lẹ bệnh nhân dùng 4 thuốc tra hạ nhãn áp giảm dần từ thời điểm 2 tuần sau điều trị với $27,5 \%$ xuống $10 \%$ ở thời điểm 1 tháng và $3 \%$ ở thời điểm 3 tháng sau điều trị. Trong số 33 mắt theo dõi được ở thời điểm 3 tháng, có 7 mắt $(21,2 \%)$ không giảm số thuốc tra, 15 mắt $(45,5 \%)$ giảm được 1 thuốc tra và 11 mắt $(33,33 \%)$ giảm được 2 thuốc tra hạ nhãn áp.

Tình trạng thị trường có sự thay đổi so với trước điều trị nhưng sự khác biệt trước và sau điêu trị không có ý nghĩa thống kê. Tương tự như vậy, sau điều trị, tất cả mắt tham gia nghiên cứu đều có độ mở từ 3 trở lên, không có bất thường về góc như hẹp, dính tại các góc phần tư. Các thông số OCT (độ dày trung bình lớp sợi thần kinh, diện tích đĩa thị, $C / D$ và thể tích đĩa thị) có xu hướng cải thiện sau điều trị, tuy nhiên không có sự khác biệt có ý nghĩa thông kê về sự thay đổi các thông số trên OCT trước và sau điều trị $(p>0,05)$. Không có sự thay đổi về tình trạng đĩa thị bao gồm các thổng số $C / D$, màu sắc, mạch máu gai thị, khuyết gai thị, quy luật ISNT, xuất huyết quanh gai trong thời gian theo dõi điều trị.

Công suất trung bình cho mỗi nốt laser là $0,90 \pm 0,09 \mathrm{~mJ}$, số nốt trung bình $96,7 \pm 3,9$ nốt, tổng năng lượng trung bình cho mỗi mắt là $87,29 \pm 10,15 \mathrm{~mJ}$. Không có sự khác biệt về mức năng lượng laser giữa các nhóm bệnh nhân ở giai đoạn bệnh khác nhau.

\section{Bảng 3. Tình trạng biến chứng}

\begin{tabular}{|c|c|c|}
\hline Biến chứng & Số mắt & Tỷ lệ (\%) \\
\hline $\begin{array}{c}\text { Cảm giác khó chịu, } \\
\text { cộm vướng }\end{array}$ & 3 & 7,5 \\
\hline Cương tụ kết mạc & 4 & 10 \\
\hline Không & 33 & 82,5 \\
\hline Tổng & 40 & 100 \\
\hline
\end{tabular}

Trong nhóm nghiên cứu không có trường hợp nào được ghi nhận có các biến chứng như phản ứng tiền phòng hay sự biến đổi đại thể cấu trúc góc tiền phòng sau điều trị tại các thời điểm khám. Có 3 mắt có cảm giác cộm vướng ngay sau điều trị và 4 mắt cương tụ kết mạc nhẹ ở thời điểm 2 tuần sau điều trị.

Bảng 4. Mức độ thành công của điều trị

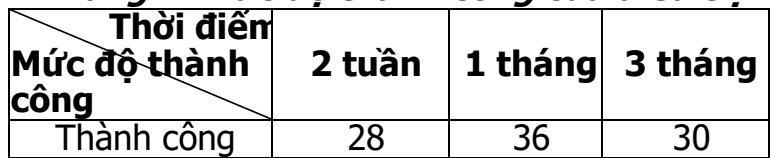




\begin{tabular}{|c|c|c|c|}
\hline & $(70 \%)$ & $(90 \%)$ & $(90,9 \%)$ \\
\hline $\begin{array}{c}\text { Không thành } \\
\text { công }\end{array}$ & 12 & 4 & 3 \\
& $(30 \%)$ & $(10 \%)$ & $(9,1 \%)$ \\
\hline Tổng & $\mathbf{4 0}$ & $\mathbf{4 0}$ & $\mathbf{3 3}$ \\
& $\mathbf{( 1 0 0 \% )}$ & $\mathbf{( 1 0 0 \% )}$ & $\mathbf{( 1 0 0 \% )}$ \\
\hline
\end{tabular}

Tỷ lệ thành công của điêu trị cao nhất ở thời điểm 3 tháng sau điêu trị với 90,9\% mắt, thấp nhất ở thời điểm 2 tuần sau điều trị với $70 \%$ mắt.

\section{BÀN LUÂN}

Các phương pháp điều trị glôcôm chủ yếu nhằm cố gắng bảo tồn các tế bào hạch võng mạc qua đó duy trì chứ không giúp tăng hay hồi phục chức năng thị giác của người bệnh, SLT cũng không phải ngoại lệ. Từ mức nhãn áp trung bình 27,48mmHg ban đầu, bệnh nhân được laser SLT $360^{\circ}$, nhãn áp trung bình tại thời điểm 3 tháng là $16,39 \mathrm{mmHg}$ với mức hạ 40,36\%. Mức hạ nhãn áp này có sự tương đồng với các nghiên cứu trước đó của Lai, Melamed và Lanzetta với mức hạ nhãn áp khoảng $40 \%$ sau điều trị ${ }^{3}$. So với Trần Anh Tuấn, mức ha nhãn áp trong nhóm bệnh nhân của chúng tôi cao hơn (40,3\% so với $33,09 \%)$, đồng thời nhãn áp trung bình trước điều trị trong nhóm bệnh nhân nhân của chúng tôi cũng cao hơn so với của nhóm tác giả trên $(27,48 \mathrm{mmHg}$ so với $25,13 \mathrm{mmHg})$, điều này có thể do đối tượng nghiên cứu của chúng tôi ở giai đoạn bênh nặng hơn. Chúng tôi cũng nhận thây thời điểm 1 tháng là khoảng thời gian tối thiểu để đánh giá hiệu quả của SLT vì thời điểm này bênh nhân đã được laser đủ toàn bộ chu vi của vù̀ng bè; kết quả cho thấy nhãn áp tại thời điểm 3 tháng tương đối tương đồng với thời điểm 1 tháng. Đánh giá mức nhãn áp hạ theo giai đoạn bênnh, chúng tôi nhận thây dường như những bệnh nhân ở giai đoạn nặng có mức hạ nhãn áp cao nhất ở thời điểm 3 tháng sau điều trị tương ứng mức giảm $42 \%$. Nhóm bệnh nhân này có nhãn áp trước điều trị cao hơn các nhóm khác trong mẫu nghiên cứu $(29 \mathrm{mmHg})$, đồng thời có mức hạ nhãn áp cũng cao nhất, điêu này phù hợp với các nghiên cứu trước đó cho rằng tỷ lệ hạ nhãn áp cao hơn trên mắt có nhãn áp trước đî̀u trị cao hơn.

Kết quả về thị lực trong nhóm nghiên cứu của chúng tôi dường như có xu hướng cải thiện sau điều trị SLT, tuy nhiên không có sự thay đổi thị lực có ý nghĩa thống kê $(p>0,05)$. Về thị trường, chúng tôi thây các chỉ số MD, PSD, VFI có thay đổi theo hướng cải thiện hơn tuy nhiên vẫn không làm thay đổi giai đoạn của bệnh, không cải thiện tình trạng chung của bệnh nhân, sư khác biệt giữa các thông số thị trường trước và sau điều trị không có ý nghĩa thống kê ( $p$ >
$0,05)$. Kết quả này tương đồng với nghiên cứu của Mahdy và cộng sự, các tác giả không thấy có sự khác biệt về thị lực, thị lực chỉnh kính và chỉ số MD trên thị trường Humphrey tại thời điểm trước và sau điêu trị ${ }^{4}$.

Tạo hình vùng bè chọn lọc bằng laser được chỉ định đối với các hình thái glôcôm góc mở mà chủ yếu là glôcôm góc mở nguyên phát, do vậy hầu hết các trường hợp đều có góc tiền phòng mở trung bình và rộng. Uu điểm của SLT là tác dụng chọn lọc trên các tế bào sắc tố mà không gầy ra các tổn thương thực thể tại vùng bè nên sau điêu trị thường không gây ảnh hưởng tới tình trạng của góc tiền phòng. Thật vậy, nhóm nghiên cứu của chúng tôi toàn bộ là bệnh nhân glôcôm góc mở nguyên phát, sắc tố góc tiền phòng chủ yếu là độ 3 , độ mở góc tiền phòng độ $3-4$. Chúng tôi không quan sát thấy bất kì dấu hiệu thay đổi về độ mở góc, tình trạng dính góc tiền phòng, hay sự thay đổi sắc tố góc tiên phòng. Kết quả này có sự tương đồng với hầu hết các nghiên cứu trước đó về tính an toàn của SLT. Đối với các nghiên cứu trong nước, chúng tôi không thây đề cập đến tình trạng góc tiền phòng sau SLT, tuy nhiên các nghiên cứu trên thế giới có lưu ý về một số ít trường hợp phân rã sắc tố mống mắt, dính góc tiền phòng, phân rã sắc tố góc tiên phòng gây tăng nhãn áp thứ phát sau SLT trên bệnh nhân glôcôm sắc tố.

Công suất trung bình cho mỗi nốt laser trong nghiên cứu của chúng tôi là $0,90 \pm 0,09 \mathrm{~mJ}$, số nốt trung bình $96,7 \pm 3,9$ nốt và tổng năng lượng trung bình cho mỗi mắt là $87,29 \pm 10,15$ $\mathrm{mJ}$. So với các nghiên cứu khác, các thông số laser của chúng tôi tương đối tương đồng. Nhiều tác giả đều cho rằng mức năng lượng laser sử dụng ít ảnh hưởng tới kết quả điều trị. Nghiên cứu của Johnson và cộng sự cho thấy mức năng lượng laser cao hơn không làm tăng tỷ lệ biến chứng ${ }^{5}$. Xu và cộng sự nghiên cứu trên 40 mắt glôcôm góc mở điều trị bằng laser $\mathrm{SLT} 360^{\circ}$ với công suất thấp từ $0,3 \mathrm{~mJ}$, tổng năng lượng $30-$ $40 \mathrm{~mJ}$ cũng cho kết quả tốt 6 .

Mặc dù SLT là phương pháp được đánh giá an toàn nhưng vẫn có những triệu chứng, tác dụng phụ ở mức thấp như tăng nhãn áp sau điều trị, đỏ mắt, cảm giác khó chịu ở mắt, phản ứng viếm tiền phòng, đây là những triệu chứng hay được ghi nhận. Cảm giác đau và khó chịu thường xảy ra sau vài giờ nhưng cũng có trường hợp sau 1 tuần thực hiện SLT. Nagar và cộng sự ghi nhận triệu chứng khó chịu và đau nhức mắt trong tuần đầu tiên sau SLT ở $20 \%$ bệnh nhân thực hiện laser $180^{\circ}$ và $39 \%$ bệnh nhân thực 
hiện laser $360^{\circ}$. Nghiên cứu của chúng tôi thây rằng tỷ lệ đau và khó chịu tại mắt thấp hơn so với các nghiên cứu trước đó với tỷ lệ đau nhức mắt là $10 \%$, cảm giác khó chiu mắt là $15 \%$ với các bệnh nhân đã thực hiện SLT 360 ${ }^{\circ}$. Điêu này có thể là nhờ bệnh nhân được tra thuốc tê 2 lần trước điều trị, tiến trình SLT được chia làm 2 đợt, mỗi đợt $180^{\circ}$ chu vi của vùng bè. Đồng thời có sự phối hợp tốt của người bệnh sau khi đã được giải thích đầy đủ giúp cho thời gian thực hiện laser nhanh hơn. Tình trạng tăng nhãn áp sau điều trị được ghi nhận trong nhiều nghiên cứu của các tác giả khác nhau như Narayanaswamy, Aljasim, Martinez-de-la-Casa và cộng sự. Trong nhóm nghiên cứu của chúng tôi, bênh nhân đa số thuộc giai đoạn trung bình và nặng, chúng tôi chủ động cho bệnh nhân dùng thuốc hạ nhãn áp đường uống và đường tra ngay sau điều trị để han chế những tổn thương thi thần kinh do tình trạng nhãn áp cao vì vậy chúng tôi không ghi nhận trường hợp nào có tăng nhãn áp thoáng qua sau điều trị và trong thời gian 2 tuần đâu sau điều trị như các nghiên cứu khác.

Đánh giá về thành công chung của điều trị chúng tôi dựa chủ yếu trên tỷ lệ \% nhãn áp hạ sau điều trị và số thuốc tra hạ nhãn áp bênh nhân phải sử dụng để duy trì được nhãn áp đích. Kết quả cho thẩy tỷ lệ thành công tại thời điểm 1 tháng là $90 \%$; 3 tháng là 90,9\%. Vể số thuốc tra hạ nhãn áp sử dụng sau điều trị, trong nghiên cứu của chúng tồi từ số thuốc tra trung bình trước điều trị $3.05 \pm 0.75$, giảm xuống đáng kể tại thời điểm 1 tháng còn 2,15 $\pm 1,1$ thuốc; 3 tháng là $1,76 \pm 0,97$ thuốc. Nghiên cứu của chúng tôi cho thấy sự giảm số lượng thuốc điều trị tại các thời điểm sau điều trị có ý nghĩa thống kê $(p<0,05)$. Kết quả của chúng tôi cũng tương tự như nghiên cứu của một số tác giả Lai và cộng sự, Keyser và cộng sự. Chúng tôi cũng nhận thấy laser $360^{\circ}$ cho hiệu quả hạ nhãn áp tốt hơn so với laser $180^{\circ}$. Mức độ thành công điều trị của ở thời điểm 1 tháng (laser $360^{\circ}$ ) cao hơn hẳn thời điểm 2 tuần (laser $180^{\circ}$ ), kết quả này tương đồng với hầu hết các nghiên cứu trước đó như của Cheema ${ }^{8}$, Maho Shibata và cộng sự9. Ngoài ra, chúng tôi thấy rằng những bệnh nhân không thành công ở thời điểm 2 tuần sau khi laser SLT $180^{\circ}$ vẫn tiếp tục cải thiện mức độ thành công ở thời điểm 1 tháng khi đã hoàn thành laser SLT $360^{\circ}$. Mặc dù nhãn áp tai thời điểm 3 tháng tuy có giảm hơn so với thời điểm 1 tháng sau điêu trị nhưng sự khác biệt không có ý nghĩa thống kê $(p>0,05)$. Đây có thể là một gợi ý cho các bác sĩ điều trị, khi bệnh nhân không xuất hiện biến chứng hoă̆c dấu hiệu tăng nặng của bệnh, có thể kiên nhẩn điều trị đủ SLT $360^{\circ}$ để đánh giá chính xác hiệu quả điều trị bằng SLT và thời điểm 1 tháng sau SLT là thời điểm thích hợp nhất để đánh giá, quyết định hướng điều trị tiểp theo cho người bệnh.

\section{KẾT LUÂNN}

Nghiên cứu của chúng tôi đã cho thấy SLT là phương pháp có tính an toàn, hiệu quả trong điều trị bệnh nhân glôcôm góc mở tra nhiều thuốc hạ nhãn áp.

\section{TÀI LIÊU THAM KHẢO}

1. Shingleton BJ, Richter CU, Dharma SK, et al. Long-term efficacy of argon laser trabeculoplasty. A 10-year follow-up study. Ophthalmology. 1993;100(9):1324-1329.

2. Anderson RR, Parish JA. Selective photothermolysis: Precise microsurgery by selective absorption of pulsed radiation. Science 1983 Apr; 220(4596):524-527.

3. Melamed S, Ben Simon GJ, LevkovitchVerbin H. Selective laser trabeculoplasty as primary treatment for open-angle glaucoma: a prospective, nonrandomized pilot study. Arch Ophthalmol. 2003;121(7):957-960. doi:10.1001/ archopht.121.7.957

4. Mahdy MA-MS. Efficacy and Safety of Selective Laser Trabeculoplasty as a Primary Procedure for Controlling Intraocular Pressure in Primary Open Angle Glaucoma and Ocular Hypertensive Patients. Sultan Qaboos Univ Med J. 2008;8(1):53-58.

5. Johnson C, Li J, Kirk C. Long Term Effect and Predictive Factors of Success for Selective Laser Trabeculoplasty (SLT). Invest Ophthalmol Vis Sci. 2018;59(9):6088-6088.

6. Xu L, Yu R-J, Ding X-M, et al. Efficacy of lowenergy selective laser trabeculoplasty on the treatment of primary open angle glaucoma. Int J Ophthalmol. doi:10.18240/ijo.2019.09.10

7. Nagar M, Ogunyomade A, O'Brart DPS, Howes F, Marshall J. A randomised, prospective study comparing selective laser trabeculoplasty with latanoprost for the control of intraocular pressure in ocular hypertension and open angle glaucoma. $\mathrm{Br} J$ Ophthalmol. 2005;89(11):1413-1417. doi:10.1136/bjo.2004.052795

8. Cheema SA, McGlynn RH, George MK, et al. Efficacy of 180 vs. 360 Degrees of Selective Laser Trabeculoplasty on Lowering Intraocular Pressure. Invest Ophthalmol Vis Sci. 2006;47(13):5466-5466.

9. Shibata $M$, Sugiyama $T$, Ishida 0 , et al. Clinical results of selective laser trabeculoplasty in open-angle glaucoma in Japanese eyes: comparison of 180 degree with 360 degree SLT. J Glaucoma. 2012;21(1):17-21. doi:10.1097/ IJG.0b013e3181fc 8020 